\title{
International regulatory landscape and integration of corrective genome editing into in vitro fertilization
}

\author{
Motoko Araki and Tetsuya Ishii
}

\begin{abstract}
Genome editing technology, including zinc finger nucleases (ZFNs), transcription activator-like effector nucleases (TALENs), and clustered regularly interspaced short palindromic repeat (CRISPR)/Cas, has enabled far more efficient genetic engineering even in non-human primates. This biotechnology is more likely to develop into medicine for preventing a genetic disease if corrective genome editing is integrated into assisted reproductive technology, represented by in vitro fertilization. Although rapid advances in genome editing are expected to make germline gene correction feasible in a clinical setting, there are many issues that still need to be addressed before this could occur. We herein examine current status of genome editing in mammalian embryonic stem cells and zygotes and discuss potential issues in the international regulatory landscape regarding human germline gene modification. Moreover, we address some ethical and social issues that would be raised when each country considers whether genome editing-mediated germline gene correction for preventive medicine should be permitted.
\end{abstract}

Keywords: Genome editing, ZFN, TALEN, CRISPR/Cas, Embryonic stem cells, Zygote, Embryo, Assisted reproductive technology, In vitro fertilization, Genetic disease, Prevention, Germline gene modification, Regulations

\section{Background}

Germline (oocyte, sperm, zygote, and embryo) gene modification has been considered to be efficacious against some genetic diseases due to its impact on the entire body of the offspring. However, there has emerged a global consensus that such gene modifications should be forbidden owing to safety concerns [1-4], unprecedented informed consent [1,2], challenges to human dignity [5], and the potential for permanent negative impact on future generations, including its abuse for eugenics or enhancement (the parental pursuit of specific traits for non-medical reasons) [2,3,6-8]. Indeed, human germline gene modification is largely forbidden by law or guidelines even in countries that are permissive to human embryonic stem cell research [9].

Meanwhile, in the late 90 's, the infusion of oocytecytoplasm, including mitochondria, was conducted to enhance the viability of oocytes in the USA [10]. This ooplasmic transfer needs an oocyte donor and is a form of germline gene modification because it causes

\footnotetext{
* Correspondence: tishii@general.hokudai.ac.jp

Office of Health and Safety, Hokkaido University, Sapporo 060-0808, Japan
}

heteroplasmy in the resulting oocyte [11,12]. Although ooplasmic transfer led to more than 30 childbirths, the Food and Drug Administration (FDA) decided to regulate this procedure owing to potential health risk to progeny [13]. More recently, mitochondrial replacement, including pronuclear transfer between embryos [14] and maternal spindle transfer between oocytes $[15,16]$, has been developed and is proposed as novel medicine in order to prevent maternal transmission of serious mitochondrial diseases that result from aberrant mitochondrial DNA (mtDNA) in patient's oocyte. Mitochondrial replacement is also a form of germline gene modification because this procedure involves altering the mtDNA content of human oocytes or embryos. In addition, mitochondrial replacement as well as ooplasmic transfer require at the very least oocyte donation which could potentially cause ovarian hyperstimulation syndrome in female donors [9]. Currently, the US FDA weighs the merits of the mitochondrial replacement [17]. Moreover, the UK Department of Health (DH) considers lifting the ban of mitochondrial replacement that is illegal in the UK at present [18]. In response to the result of public 
consultation, the $\mathrm{DH}$ will consider the timing of the regulations to permit mitochondrial replacement [19]. Such possible regulatory changes, which occur in a few, but major countries, may impact the international regulatory landscape that prohibits human germline gene modification.

Recent advances in genetic engineering are also likely to impact the international regulatory landscape. Present-day genome editing technology, such as zinc finger nucleases (ZFNs), transcription activator-like effector nucleases (TALENs), and clustered regularly interspaced short palindromic repeat (CRISPR)/Cas system, have achieved far more efficient genetic engineering in higher organisms than the older techniques [20-23]. Of genome editing technologies, the application of ZFNs has already reached to a clinical stage in AIDS therapy that is based on the administration of human chemokine receptor 5 (CCR5)-modified T cells [24]. ZFN-mediated homologydirected repair has achieved correction of the mutations associated with X-linked severe combined immune deficiency (SCID) and haemostasis in somatic cells [25,26]. Moreover, gene corrections by ZFNs have been reported regarding induced pluripotent stem cells derived somatic cells biopsied from patients with sickle cell disease, alpha1-antitrypsin deficiency, and Parkinson's disease [27-30]. With regard to CRISPR/Cas9, it was demonstrated that those engineered nucleases can correct a mutation in intestinal stem cells derived from patients with cystic fibrosis [31]. Specific elimination of mutant mitochondrial genomes in patient-derived cells was attained by a new form of TALENs that can localize to mitochondria and cleave different classes of pathogenic mtDNA mutations [32].

Most notably, two reports emerged in 2014, demonstrating that the microinjection of Cas9 or TALENs into one-cell-stage embryos led to efficient generation of targeted gene-modified non-human primates (NHPs) $[33,34]$. In addition, the microinjection of Cas9 system into mouse zygotes successfully corrected a 1 bp deletion in a targeted gene and prevented the onset of cataracts in that mouse's offspring [35]. Thereafter, some experts, including a Nobel laureate, suggest increasing feasibility of human germline gene modification mediated by genome editing [36-38]. In the genome editing of mammals, targeted gene modification is frequently carried out by simply microinjecting of genome editing system which consists of the nuclease mRNAs (or plasmids harboring the nuclease gene), single guide RNAs (sgRNAs for Cas9), and a homology-containing donor DNA template (if necessary) into animal embryos made by in vitro fertilization (IVF) or intracytoplasmic sperm injection (ICSI) [33-35,39-48]. Remarkably, this microinjection process resembles ICSI, one of assisted reproductive technology (ART) to facilitate fertilization in fertility clinics. Mammalian embryonic stem cells (ESCs), including human ESCs, have also been more efficiently modified by genome editing [35,42,43,49-53]. Thus, rapid advances in genetic engineering render germline gene modification more feasible in higher animals. Genome editing technology is more likely to develop into medicine for preventing a genetic disease if corrective genome editing is integrated into assisted reproductive technology (ART), including IVF and ICSI. Importantly, germline gene correction by genome editing does not require cell donation such as oocyte donation that is needed for ooplasmic transfer and mitochondrial replacement. However, there are many issues that still need to be addressed before genome editing-mediated germline gene correction for preventive medicine could occur. We herein investigated current status of genome editing which modifies mammalian zygotes and embryonic stem cells as well as international regulations with regard to human germline gene modification. As a consequence, it was predicted that there would occur regulatory issues surrounding genome editing-mediated germline gene correction worldwide when the efficiency of genome editing technology is further improved. Moreover, we discuss forthcoming ethical and social issues that corrective genome editing would raise in the field of reproductive medicine.

\section{Potential subjects for genome editing-mediated germline gene correction}

Genetic engineering can produce site-specific mutations in cells or an organism. However, conventional genetic engineering can be extremely laborious and require time-consuming screens to identify a desired gene modification particularly in higher organisms. Genome editing technology is more efficient genetic engineering that can directly modify a gene within a genome in various organisms. This efficient gene modification is attained by a microorganism-originated, engineered nuclease that causes double-stranded breaks (DSBs) at a targeted sequence and induces DNA repair through non-homologous end-joining (NHEJ) or homology-directed repair (HDR) (Figure 1). The NHEJ is a DSB repair pathway that ligates or joins two broken ends together without a homologous template for repair, thus leading to the introduction of small insertions or deletions (indels) at the site of the DSB. The HDR is a DNA template-dependent pathway for DSB repair, using a homology-containing donor template along with a site-specific genome editing nuclease, enabling the insertion of single or multiple transgenes (gene addition) in addition to single-nucleotide substitutions in which an amino acid substitution of a protein occurs (gene modification), or a mutation is completely repaired in the resultant organism genome (gene correction). Remarkably, genome editing technologies do 




not leave marked genetic vestiges such as residual loxP sites that result from the Cre/loxP recombination system in transgenic mice, following the modifications. However, there are still some technical issues in genome editing. Identifying desired cells or animals which have an intentional mutation among arising variants still require careful screening, despite less laborious than conventional methods. Moreover, genome editing technology may fail to induce a biallelic modification in an animal, thereby resulting in only an animal with a monoallelic modification. The engineered nucleases could also cause off-target mutations other than desired gene modification in a target sequence [35,39-41,44,49-51]. Furthermore, the microinjection of the nuclease mRNAs into zygotes may induce not only germline modifications but also mosaic modifications in which wild-type cells, including germline cells, and genetically modified cells coexist in the resultant animals $[41,47]$. Therefore, the entire process of genome editing must be cautiously controlled by genetic analysis, meticulous screening, and sufficient characterization of resulting animals.

If corrective genome editing is integrated into ART, represented by IVF and ICSI, the major medical implications of the germline gene correction are preventive medicine rather than therapy, because this type of medical procedure aims at not the treatment of existing patients, but the prevention of transmission of a genetic disease to offspring [54]. For this reason, potential subjects would include those with congenital anomalies that are caused by chromosomal, monogenic, multifactorial, or environmental/teratogenic factors [55]. Among these, a monogenic disease would be the initial candidate for clinical application, since genome editing can efficiently repair such a small mutation in the human germline. However, medical use of genome editing for preventing transmission of a monogenic disease should be limited to cases where the medical benefits exceed the potential health risks associated with the genetic intervention, implying definite inheritance by the offspring. For instance, an autosomal recessive disease in which both parents are homozygous (e.g. cystic fibrosis [56], phenylketonuria [57]) or an autosomal dominant disease where at least one parent is homozygous (e.g. Huntington's disease [58], familial adenomatous polyposis [59]) is likely to be considered. Genome editing-mediated germline gene correction which could potentially cause off-target mutations is not likely to be considered elsewhere for the time being because preimplantation genetic diagnosis (PGD) may circumvent an affected pregnancy by selecting IVF embryos with no suspected mutations [60].

Although clinical cases in which genome editingmediated germline gene correction is efficacious and 
applicable might be confined to parents with a specific genetic background, as well as a monogenic disease, such cases will likely be found. If affected parents use a medical procedure that prevents offspring from inheriting their devastating disease, the public would sympathize with them, similar to the case in mitochondrial replacement [9]. One might assert that affected parents should not use such a risky genetic intervention, and should instead use donor gametes or donor embryos. However, the parents should not be forced to use these reproductive options. Most parents wish to have their own genetically-related healthy child. Therefore, the use of such a medical procedure could represent an alternative reproductive option.

\section{Approaches for genome editing-mediated gene correction}

We considered two possible approaches for genome editing-mediated germline gene correction to prevent definite inheritance of a genetic disease (Figure 2). If one attempts to repair a mutation directly in oocytes or embryos by means of an older homologous recombination technique, this attempt is likely to be a failure owing to its low efficiency. Therefore, genome editing-mediated

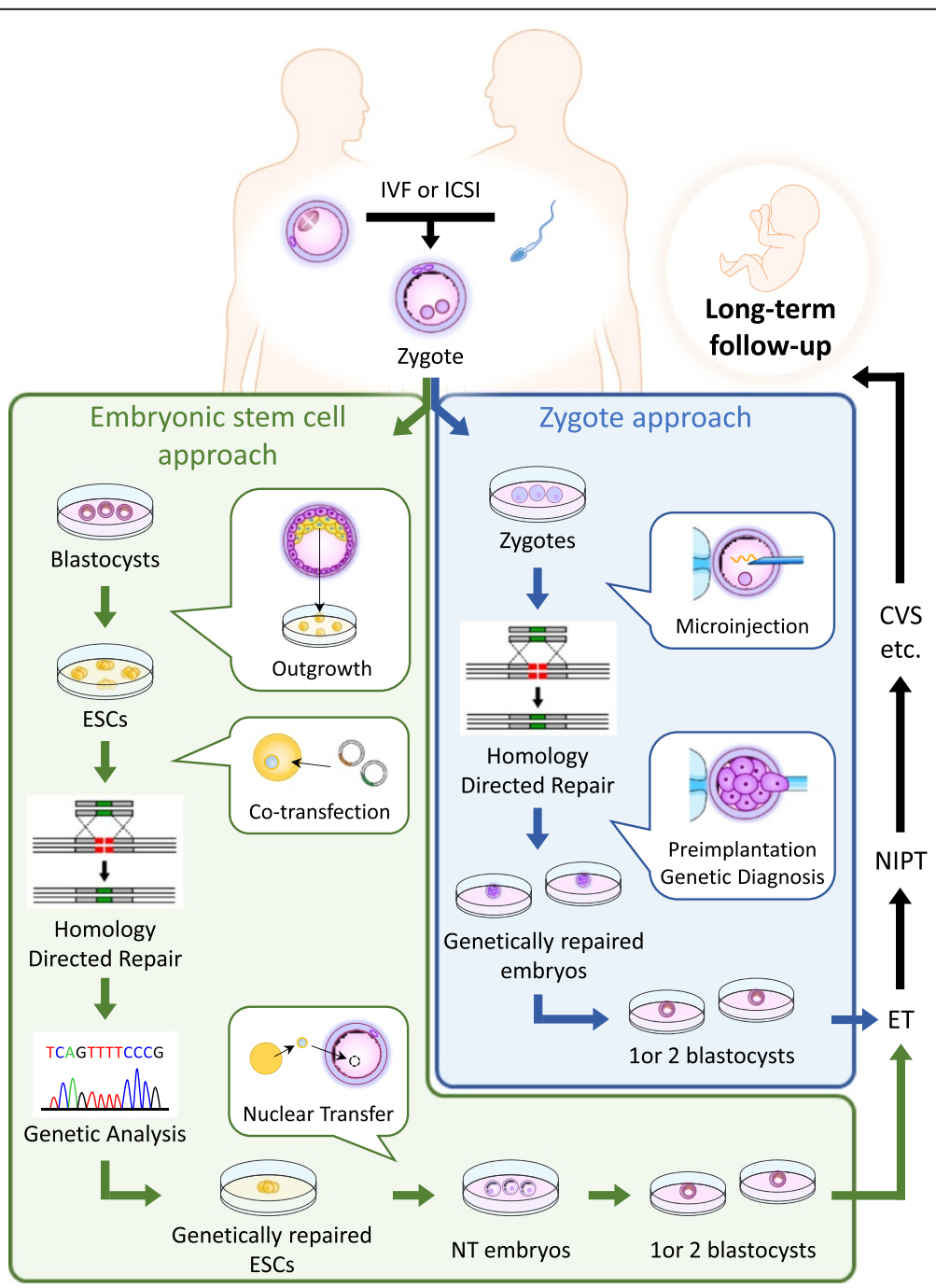

Figure 2 Embryonic stem cell approach and zygote approach for genome editing-mediated gene correction to prevent a genetic disease. Zygotes with a mutation are treated with genome editing-mediated gene correction via embryonic stem cell approach or zygote approach. After embryo screening by preimplantation genetic diagnosis, one or more embryos which have a corrected gene with no off-target mutations are subjected to embryo transfer. NIPT can be used to confirm the genetic condition of the fetus. Subsequently, CVS or amniocentesis can confirm whether a fetus has genetic mosaic mutations. Long-term follow-up is required even after a successful birth owing to the contribution of the modified germline to the entire body. CVS: chorionic villus sampling, ESCs: embryonic stem cells, ET: embryo transfer, ICSI: intracytoplasmic sperm injection, IVF: in vitro fertilization, NIPT: non-invasive prenatal genetic testing, NT: nuclear transfer. 
gene correction in ESCs which are derived from a parent's embryo made by IVF or ICSI could represent an alternative approach. Taking advantage of the self-renewal of ESCs, in vitro expansion and cryopreservation of ESCs enables repeated attempts to correct a mutation in a specific gene by genome editing. According to reports regarding genome editing of mammalian ESCs, the efficiencies of indel and gene addition are 14 to $91 \%$ by Cas 9 and 0 to $83.49 \%$ by ZFNs or TALENs, respectively (Table 1). Importantly, the efficiency, $83.49 \%$ was achieved in a human ESC experiment for gene addition by ZFNs. The efficiency of NHEJ-mediated indel is high even in the simultaneous mutations of three loci $(14 \%, 21 \%)$. In contrast, the efficiency of the HDR-mediated gene addition may depend on the selection of a targeted gene. Of note, both ZFNs and TALENs could not attain homozygous gene addition in the OCT4 of human ESCs [50,51]. Compared with these results regarding indel and gene addition, the efficiency of targeted gene correction by ZFNs or Cas9 is low in human ESCs (Table 1). On a closer examination, however, the efficiency of gene correction of integrated GFP with ZFNs was $0.24 \%$, a $>2400$-fold increase as compared with gene correction without ZFNs in Human ESCs [52]. In mouse ESCs, the best result of gene correction, $44.4 \%$ was obtained in a case of a well-designed guide RNA in Cas9 system (Table 1), although two occurrences of off-target mutations were observed [35]. Off-target mutations were also observed in the three reports regarding gene addition in human ESCs [49-51]. In preclinical research, meticulously designing and validating Zinc finger domains in ZFNs, TALE subunits in TALENs, and sgRNAs in CRISPER/Cas which are specific to a target site of a gene is required in order to maximize the efficiency of desired gene modification and minimize the possibility of off-target mutations in genome editing-mediated gene correction.

Such outcome suggests the attainability of genome editing-mediated gene correction in some cases of human ESCs if modified ESCs are carefully analysed regarding the occurrence of off-target mutations. Subsequently, a karyoplast removed from a genetically corrected ESC can be transferred to an enucleated oocyte retrieved from a female parent, and the resultant embryo can be cultured and transferred to the female recipient. The step is also considered to be potentially feasible in human because a similar approach with somatic cells modified by ZFNs has already been used for the generation of a biallelic knockout in pigs [61]. Additionally, human somatic cell nuclear transfer (SCNT)-derived blastocysts have been recently produced by at least three independent groups [62-64]. Remarkably, the approach does not imply cloning of a living human if this is used only once for the birth of one child. Nonetheless, the ESC approach has some disadvantages. There might be a potential risk of xeno

Table 1 Genome editing of mammalian embryonic stem cells

\begin{tabular}{|c|c|c|c|c|c|c|}
\hline Subject & Targeted Gene & Efficiency of Modification ${ }^{*}$ & Off-target Mutation & $\begin{array}{c}\text { Genome } \\
\text { Editing }\end{array}$ & $\begin{array}{l}\text { Delivery } \\
\text { Method }\end{array}$ & Ref. \\
\hline \multicolumn{7}{|c|}{ NHEJ for InDel } \\
\hline $\begin{array}{l}\text { Rat haploid } \\
\text { ESCs }\end{array}$ & Tet1, Tet2, Tet3 & $\begin{array}{c}\text { 91\% (Single locus), } 45 \% \text { (Double), } \\
\text { 14\% (Triple) }\end{array}$ & N.D. & Cas9 & Plasmid/sgRNA & [53] \\
\hline Mouse ESCs & Tet1, Tet2, Tet3, Sry, Uty & $\begin{array}{l}56 \sim 77 \% \text { (Single; Tet1,2,3), 21\% } \\
\text { (Triple; Tet1,2,3) }\end{array}$ & No & Cas9 & Plasmid & [43] \\
\hline \multicolumn{7}{|c|}{ HDR for Gene Addition } \\
\hline $\begin{array}{l}\text { Human } \\
\text { ESCs }\end{array}$ & GFP into CCR5 & $5.3 \%$ & Yes & ZFNs & Lentivirus & [49] \\
\hline $\begin{array}{l}\text { Human } \\
\text { ESCs }\end{array}$ & PGK-Hygro ${ }^{R}$ into, PIG-A & $0.19 \sim 83.49 \%$ & N.D. & ZFNs & Plasmid & [52] \\
\hline $\begin{array}{l}\text { Human } \\
\text { ESCs }\end{array}$ & $\begin{array}{l}\text { GFP (or PURO) into, AAVS1, OCT4, } \\
\text { PITX }\end{array}$ & $\begin{array}{c}2.9 \sim 15.2 \% \text { (AAVS1), } 0 \% \text { (OCT4, } \\
\text { PITX3) }\end{array}$ & $\begin{array}{l}\text { No (AAVS1, OCT4), Yes } \\
\text { (PITX3) }\end{array}$ & ZFNs & Plasmid & {$[50]$} \\
\hline $\begin{array}{l}\text { Human } \\
\text { ESCs }\end{array}$ & $\begin{array}{c}\text { GFP (and/or PURO), into. AAVS1, } \\
\text { OCT4, PITX3 }\end{array}$ & $\begin{array}{c}9 \sim 22 \% \text { (AAVS1), } 1 \sim 2 \% \text { (PITX3), } \\
0 \%(\text { OCT4) }\end{array}$ & $\begin{array}{l}\text { Yes (AAVS1, OCT4), N. } \\
\text { D. (PITX3) }\end{array}$ & TALENS & Plasmid & [51] \\
\hline \multicolumn{7}{|c|}{ HDR for Gene Correction or Modification } \\
\hline $\begin{array}{l}\text { Human } \\
\text { ESCs }\end{array}$ & Removal of Integrated GFP & $0.24 \%$ & N.D. & ZFNs & Plasmid & {$[52]$} \\
\hline $\begin{array}{l}\text { Human } \\
\text { ESCs }\end{array}$ & $\begin{array}{l}\text { Introduction of Hindl|l cleavage } \\
\text { site into EMX1 }\end{array}$ & $0.4 \%$ & No & $\begin{array}{l}\text { Cas9 nickase } \\
\text { mutant }\end{array}$ & $\begin{array}{l}\text { Plasmid/ } \\
\text { sgRNA/Oligo }\end{array}$ & [42] \\
\hline Mouse ESCs & Crytg with 1 bp deletion in exon3 & $0 \sim 44.4 \%$ & Yes & Cas9 & Plasmid & [35] \\
\hline
\end{tabular}

ESCs; embryonic stem cells, NHEJ; non-homologous end-joining, HDR; homology-directed repair, GFP; green fluorescent protein, PURO; puromycin, sgRNA; single guide RNA, N.D.; not determined.

*Biallelic modification. 
contamination if mouse feeder cells, fetal bovine serum, or recombinant growth factors from non-human species are used in human ES medium. However, this risk can be circumvented if a xeno-free culture system is adopted. Moreover, although electroporation or transfection reagents might cause cytotoxicity [52], preliminary research would decrease such risks. Most importantly, uncertainties may occur due to the complexity of this approach. Human ESCs have a progressive tendency to acquire genetic changes in the nucleus and/or mitochondria during prolonged culture [65-68]. Moreover, not all ESC colonies in a dish are composed of the same clones. Mutant clones might be mixed into a colony during a subsequent NT procedure.

In contrast to the ESC approach, zygote approach is best characterized by fewer steps (Figure 2). Genome editing system is simply injected into the cytoplasm or pronuclear of zygotes to correct a mutation in a gene. After embryo screening, one or more embryos which have a corrected gene with no off-target mutations are then subjected to embryo transfer. Non-invasive prenatal genetic testing, which uses maternal blood containing cell-free fetal DNA [69], can be used to confirm the genetic condition of the fetus. Subsequently, invasive genetic testing, such as chorionic villus sampling or amniocentesis, can confirm whether a fetus has genetic mosaic mutations, although these diagnostics are associated with a potential risk of miscarriage. Long-term follow-up would be required even after a successful birth owing to the contribution of the modified germline to the entire body.

Microinjection of genome editing system into mammalian zygotes frequently results in efficient gene modification. According to recent reports, the efficiency of indel in a single gene by TALENs or Cas9 ranges from $0.5 \%$ to $40.9 \%$ per injected zygotes (Table 2). Remarkably, the efficiency, $40.9 \%$ was attained in non-human primate (NHP) embryos by injecting Cas9 system composed of mRNAs and sgRNAs. In this experiment, a set of twin female neonates with both modified Rag1 and Ppar- $\gamma$ were born. In addition, Ran et al. reported that Cas9 nickase treatment can induce indels in Mecp2 at 80 to 100 percent of mouse blastocysts [42]. Regarding gene modification in neonates, the efficiencies of indel and gene addition are 0 to $41.7 \%$ by TALENs or Cas 9 , and 1.7 and $3.0 \%$ by Cas9, respectively (Table 2 ). In the targeted gene correction or modification, the efficiency is 2.0 to $6.0 \%$ in mouse neonates (Table 2). However, these gene correction or modification experiments resulted in the occurrence of off-target mutations (Table 2). The use of Cas9 nickase mutant resulted in less off-target mutations than wild type Cas9, but could not solve the off-target problem completely [44]. The Cas9-mediated HDR by an exogenously provided oligonucleotide or the endogenous wild type allele was accompanied by rare but significant off-target mutations in the mouse gene correction experiment [35]. Moreover, although no detectable mutations were found in the predefined potential offtarget sites in the modified NHPs [33,34], in another NHP experiment, a modified monkey which was treated with TALENs appeared to be mosaic [47] (Table 2).

Zygote approach requires the PGD from the cleavagestage (on day 3 of development) to blastocyst stage (on day 5 of development) to confirm no off-target mutations and complete correction of a mutation prior to embryo transfer. Although no mutations were detected in the predefined potential off-target sites in the NHPs in previous studies [33,34], careful prior investigation is needed to assess whether PGD can definitely confirm genetic conditions in modified embryos. The PGD entails the opening of the zona pellucida and the removal of embryonic cell(s) from an embryo [60]. It implies that the embryo undergoes physical interventions twice, namely, microinjection of the genome editing system, and the biopsy for PGD. If ICSI is used to increase a success rate of fertilization and avoid polyspermy, three interventions are conducted. Such physical interventions might affect the subsequent development of the embryos in vitro or in vivo. Moreover, a PGD is also challenging and needs preclinical optimization because accurate genetic testing depends on biopsied embryonic cell(s). Since a cleavage-stage embryo is composed of six to eight cells, a single cell biopsy is widely used for PGD [60]. However, mosaicism which affects $15-80 \%$ of embryos may impact the interpretation of PGD results [70-72]. Meanwhile, in the blastocyst stage, the embryo consists of approximately 130 cells in the inner cell mass which subsequently develops into the fetus and the surrounding trophectoderm. Recently, trophectoderm cells have been biopsied from a blastocyst for PGD in order to avoid damaging the embryo [60]. Although mosaicism remains at the blastocyst stage [70-72], the result of a recent randomized clinical trial supports that a single cell biopsy at the cleavage-stage is more significantly damaging to the embryo than biopsy at the blastocyst stage, and resulted in poorer clinical outcomes [73]. Therefore, sufficiently optimized, trophectoderm biopsy-based PGD may be effective in the zygote approach.

Furthermore, the microinjection of genome editing system into one-cell-stage embryos needs scrutiny at the molecular level. The nuclear status transitions occur during the one-cell-stage, encompassing the separated oocyte and sperm pronuclei, pronuclear fusion, and cleavage to the two-cell-stage. Currently, pronuclear injection and cytoplasmic injection are adopted to introduce genome editing system into mammalian zygotes (Table 2). For this reason, the injection method and timing of microinjection must be optimized since 
Table 2 Genome editing of mammalian zygotes

\begin{tabular}{|c|c|c|c|c|c|c|c|c|}
\hline Subject & Targeted Gene & $\begin{array}{l}\text { Efficiency in } \\
\text { Embryos }{ }^{*}\end{array}$ & $\begin{array}{l}\text { Efficiency in } \\
\text { Neonates }^{* *}\end{array}$ & $\begin{array}{l}\text { Off-target } \\
\text { Mutation }\end{array}$ & $\begin{array}{c}\text { Genome } \\
\text { Editing }\end{array}$ & $\begin{array}{l}\text { Delivery } \\
\text { Method }\end{array}$ & Remarks & Ref. \\
\hline \multicolumn{9}{|c|}{ NHEJ for InDel } \\
\hline $\begin{array}{l}\text { Monkey, } \\
\text { zygotes }\end{array}$ & $\begin{array}{l}\text { NrOb1,Ppar- } \gamma_{1} \\
\text { Rag1 }\end{array}$ & $\begin{array}{l}\text { 18.2 40.9\%, } \\
\text { (Single), } 9.1 \sim \\
27.3 \% \text { (Double) }\end{array}$ & - & No & Cas9 & $\begin{array}{l}\text { mRNA/ } \\
\text { sgRNA }\end{array}$ & $\begin{array}{c}\text { A set of twin female monkeys } \\
\text { with modified Rag1 and Ppar- } \gamma \\
\text { were born. }\end{array}$ & [33] \\
\hline $\begin{array}{l}\text { Monkey, } \\
\text { zygotes }\end{array}$ & MECP2 & - & $\begin{array}{l}\text { 9.5\% (Rhesus), 3.7\% } \\
\text { (Cynomolgus) }\end{array}$ & No & TALENs & Plasmid & $\begin{array}{c}\text { Three miscarried rhesus and } \\
\text { cynomologus male fetuses had } \\
\text { Mecp2 mutations. }\end{array}$ & [34] \\
\hline $\begin{array}{l}\text { Monkey, } \\
\text { zygotes }\end{array}$ & MECP2 & - & $(2.0 \%)$ & N.D. & TALENS & mRNA & $\begin{array}{l}\text { A modified male monkey } \\
\text { appeared to be mosaic. }\end{array}$ & [47] \\
\hline $\begin{array}{l}\text { Bovine, } \\
\text { zygotes }\end{array}$ & LDLR & $3.8 \%$ & - & N.D. & TALENS & mRNA & Cytoplasmic injection & [46] \\
\hline $\begin{array}{l}\text { Porcine, } \\
\text { zygotes }\end{array}$ & RELA & $0.5 \%$ & - & N.D. & TALENs & mRNA & Cytoplasmic injection & {$[46]$} \\
\hline $\begin{array}{c}\text { Rat, } \\
\text { zygotes }\end{array}$ & $\lg M$ & - & $3.9 \sim 5.5 \%$ (mRNA) & $\begin{array}{l}\text { No (Plasmid), } \\
\text { Yes (mRNA) }\end{array}$ & TALENs & $\begin{array}{l}\text { Plasmid } \\
\text { or mRNA }\end{array}$ & $\begin{array}{l}\text { Mosaic mutations occurred. } \\
\text { Plasmid; Pronuclear, mRNA; } \\
\text { Cytoplasmic injection. }\end{array}$ & [39] \\
\hline $\begin{array}{c}\text { Rat, } \\
\text { Zygotes }\end{array}$ & Tet1,Tet2,Tet3 & - & $\begin{array}{c}14.3 \sim 18.8 \% \\
\text { (Double; Tet1,2), } \\
\text { 18.6\% (Triple) }\end{array}$ & Yes (Triple) & Cas9 & $\begin{array}{l}\text { mRNA/ } \\
\text { sgRNA }\end{array}$ & $\begin{array}{l}\text { Mosaic mutations occurred. } \\
\text { Cytoplasmic injection }\end{array}$ & {$[41]$} \\
\hline $\begin{array}{l}\text { Mouse, } \\
\text { Zygotes }\end{array}$ & $\begin{array}{l}\text { Tet1,Tet2,Tet3, } \\
\text { Sry, Uty }\end{array}$ & - & $\begin{array}{c}8.0 \sim 17.6 \% \text { (Single), } \\
14.7 \sim 15.3 \% \\
\text { (Double; Tet } 1,2)\end{array}$ & $\begin{array}{l}\text { No (Tet1,Tet2), } \\
\text { N.D. (Tet3) }\end{array}$ & Cas9 & $\begin{array}{l}\text { mRNA/ } \\
\text { sgRNA }\end{array}$ & Pronuclear injection & [43] \\
\hline $\begin{array}{l}\text { Mouse, } \\
\text { zygotes }\end{array}$ & Mecp2 & $80 \sim 100 \%^{\dagger}$ & - & No & $\begin{array}{l}\text { Cas9, } \\
\text { nickase } \\
\text { mutant }\end{array}$ & $\begin{array}{l}\text { mRNA/ } \\
\text { sgRNA }\end{array}$ & Cytoplasmic injection & [42] \\
\hline $\begin{array}{l}\text { Mouse, } \\
\text { zygotes }\end{array}$ & Exo1 & $1.4 \sim 6.8 \%$ & $0 \sim 10.3 \%$ & N.D. & TALENs & mRNA & Pronuclear injection & [48] \\
\hline $\begin{array}{l}\text { Mouse, } \\
\text { zygotes }\end{array}$ & Fgf10 & - & $14.3 \sim 41.7 \%$ & N.D. & Cas9 & $\begin{array}{l}\text { mRNA/ } \\
\text { sgRNA }\end{array}$ & Cytoplasmic injection & {$[45]$} \\
\hline $\begin{array}{l}\text { Mouse, } \\
\text { zygotes }\end{array}$ & Fgf10 & - & $1.3 \sim 1.5 \%$ & N.D. & TALENs & $\begin{array}{l}\text { mRNA/ } \\
\text { sgRNA }\end{array}$ & Cytoplasmic injection & {$[45]$} \\
\hline \multicolumn{9}{|c|}{ HDR for Gene Addition } \\
\hline $\begin{array}{l}\text { Mouse, } \\
\text { zygotes }\end{array}$ & $\begin{array}{c}\text { mCherry into } \\
\text { Nanog, GFP into } \\
\text { Oct4 }\end{array}$ & - & $\begin{array}{l}\text { 1.7\% (Nanog), } \\
\text { 3.0\% (Oct4) }\end{array}$ & $\begin{array}{l}\text { Yes, (Nanog, } \\
\text { Oct4) }\end{array}$ & Cas9 & $\begin{array}{l}\text { mRNA/ } \\
\text { sgRNA/ } \\
\text { Plasmid }\end{array}$ & $\begin{array}{c}\text { Cytoplasmic or pronuclear } \\
\text { injection }\end{array}$ & [40] \\
\hline \multicolumn{9}{|c|}{ HDR for Gene Correction or Modification } \\
\hline $\begin{array}{l}\text { Mouse, } \\
\text { zygotes }\end{array}$ & $\begin{array}{l}\text { Addition of V5 } \\
\text { to Sox2, lox to } \\
\text { Mecp2 }\end{array}$ & - & $\begin{array}{c}6.0 \% \text { (Sox2) } \\
0.8 \% \text { (Mecp2) }\end{array}$ & Yes (Mecp2) & Cas9 & $\begin{array}{l}\text { mRNA/ } \\
\text { sgRNA/ } \\
\text { Oligo }\end{array}$ & $\begin{array}{l}\text { Cytoplasmic or pronuclear } \\
\text { injection }\end{array}$ & [40] \\
\hline $\begin{array}{l}\text { Mouse, } \\
\text { zygotes }\end{array}$ & $\begin{array}{l}\text { Crytg with } 1 \text { bp } \\
\text { deletion in } \\
\text { exon3 }\end{array}$ & - & $4.4 \sim 5.7 \%$ & Yes & Cas9 & $\begin{array}{l}\text { mRNA/ } \\
\text { sgRNA/ } \\
\text { Oligo }\end{array}$ & Cytoplasmic injection & [35] \\
\hline $\begin{array}{l}\text { Mouse, } \\
\text { zygotes }\end{array}$ & $\begin{array}{l}\text { Introduction of } \\
\text { a STOP codon } \\
\text { into Fah }\end{array}$ & - & $\begin{array}{l}2.0 \% \text { (wild type), } \\
2.0 \% \text { (nickase } \\
\text { mutant) }\end{array}$ & $\begin{array}{c}\text { Yes, } \\
\text { (mutant }<\text { WT) }\end{array}$ & $\begin{array}{l}\text { Cas9 WT } \\
\text { and } \\
\text { mutant }\end{array}$ & $\begin{array}{l}\text { mRNA/ } \\
\text { sgRNA/ } \\
\text { Oligo }\end{array}$ & Pronuclear injection & {$[44]$} \\
\hline
\end{tabular}

${ }^{*}$ Genetically modified embryos per injected zygote (\%). **Genetically modified neonates (including fetus) per transferred embryo (\%). †Genetically modified blastocysts per blastocyst which underwent Cas9 treatment (\%).

incomplete gene correction by inappropriate microinjection may fail to prevent a genetic disease. In addition, the cytotoxicity caused by the genome editing system introduced in the form of a plasmid, mRNA, or protein, with or without the short repair template DNA, should be respectively investigated [21]. In doing so, the best dose should also be considered to assure a complete
DNA repair with less cytotoxicity. In recent two reports, it was demonstrated that ZFN and TALEN proteins are capable of crossing cell membranes and inducing endogenous gene disruption [34,74]. This approach, despite difficulty in the preparation of the protein, has some advantages over DNA-based delivery methods. This delivery method can limit the time that cells are exposed 
to such nucleases, potentially minimizing off-target activity. Moreover, this method reduces the cell-type dependency and toxicity of viral and nonviral gene delivery systems.

Collectively, the zygote approach has advantages over the ESC approach in terms of its simplicity, implying that it may be more controllable protocol. Additionally, the zygote approach is not associated with the potential ethical issues of human cloning discussed in the ESC approach. If more efficient gene correction is attained by improved genome editing, and if 13 to 15 oocytes, which is optimum number of oocytes for a successful first IVF cycle $[75,76]$, can be retrieved from female patients, zygote approach is more likely to be feasible in a clinical setting. One of the latest genome editing system, Cas9 is increasingly used for zygote approach due to the ease of preparation (Table 2). In contrast, Cas9 is considered to cause higher off-target mutations than ZFNs and TALENs [42]. However, Cas9 has been rapidly improved, demonstrating that the combination of a Cas9 nickase mutant and paired gRNAs, the truncation of gRNAs, or the fusion of inactive Cas9 to Fok I nuclease can improve the specificity of targeted gene modification $[42,77,78]$. Although there might be difficulties in preclinical optimization, rapid advances in genome editing would make technical obstacles surmounted, and develop germline gene correction into a medical procedure in the immediate future.

\section{International regulatory landscape}

The preclinical research being performed to optimize the microinjection of genome editing system into onecell-stage embryos requires human embryos for research use. However, for ethical reasons, many countries or states have strict regulations regarding the creation of human embryos for research [79]. Yet, in some countries, surplus cryopreserved embryos which were originally created by IVF or ICSI and are no longer used for reproduction are available, and researchers are permitted to derive ESCs from the surplus embryos as long as they have informed consent of the parents who underwent fertility treatment, after approval of an institutional review board (IRB) or equivalent bodies, and/or a national review. Such surplus IVF embryos might facilitate optimizing the microinjection procedure if the culture period is within the 14th day of embryo development or until the beginning of formation of primitive streak [79].

More importantly, as mentioned in the Background, many countries ban human germline gene modification. We recently surveyed fourteen countries which are permissive to human ESC research, with regard to whether these countries permit human germline gene modification [9]. The result showed that thirteen of these countries prohibit the gene modification, and in the USA,
FDA regulates the clinical trial, whereas the NIH restricts the application of germline gene modification. In order to examine an international regulatory landscape, we expanded our survey to 39 countries which included the 14 countries. As a result, 29 countries were found to ban germline gene modification. The remaining 10 countries include 9 countries which were ambiguous about the legal status of the modification, and the USA (Figure 3, see Additional file 1: Table S1).

Among the 29 countries, China, India, Ireland, and Japan forbid it based on guidelines that are less enforceable than laws, and are subject to amendment (Additional file 1: Table S1). The regulatory landscape suggests that human germline gene modification is not totally prohibited worldwide although there is room for further investigation regarding the "ambiguous" countries. Again, the USA currently does not ban, but has imposed a temporary moratorium on the germline gene modification under the FDA vigilance and the NIH guidelines (Additional file 1: Table S1). When the safety of genome editing-mediated germline gene correction is enhanced, the four countries mentioned above and the USA might permit it. In addition, Israel, which explicitly bans germline gene modification, but has possible exemptions in the relevant law may permit it upon the recommendation of an advisory committee [9]. This Israeli law is temporary legislation until May 23, 2016 (Additional file 1: Table S1). After that, the country might permit human germline gene modification. In the UK, the $\mathrm{DH}$ will consider the timing of the regulations to permit mitochondrial replacement that is currently illegal mtDNA alternation in the germline [19]. However, carefully taking into consideration that there is no legal ban on research on the human germline gene modification as long as the Human Fertilisation and Embryology Authority (HFEA) licenses such research in the UK, the legalization of medical use of mitochondrial replacement is likely to lead to legal permission for the modification of germline nuclear genome that can be readily changed by genome editing technology [80].

We recently argued that there are indistinct regulatory boundaries regarding genome editing technology created in the regulations that govern genetically modified organisms (GMOs) [81]. One of the major issues was how organisms modified using genome editing are viewed in the process-based or product-based GMO regulations. A similar debate may occur regarding the medical use of genome editing. Remarkably, Belgium, Bulgaria, Canada, Denmark, Sweden, and the Czech Republic ban germline gene modification on the grounds that a modified gene may be inherited by offspring or that the gene modification may impair human embryo (Additional file 1: Table S1). However, it is unclear whether genome editing-mediated germline gene correction is rendered illegal in those countries when 


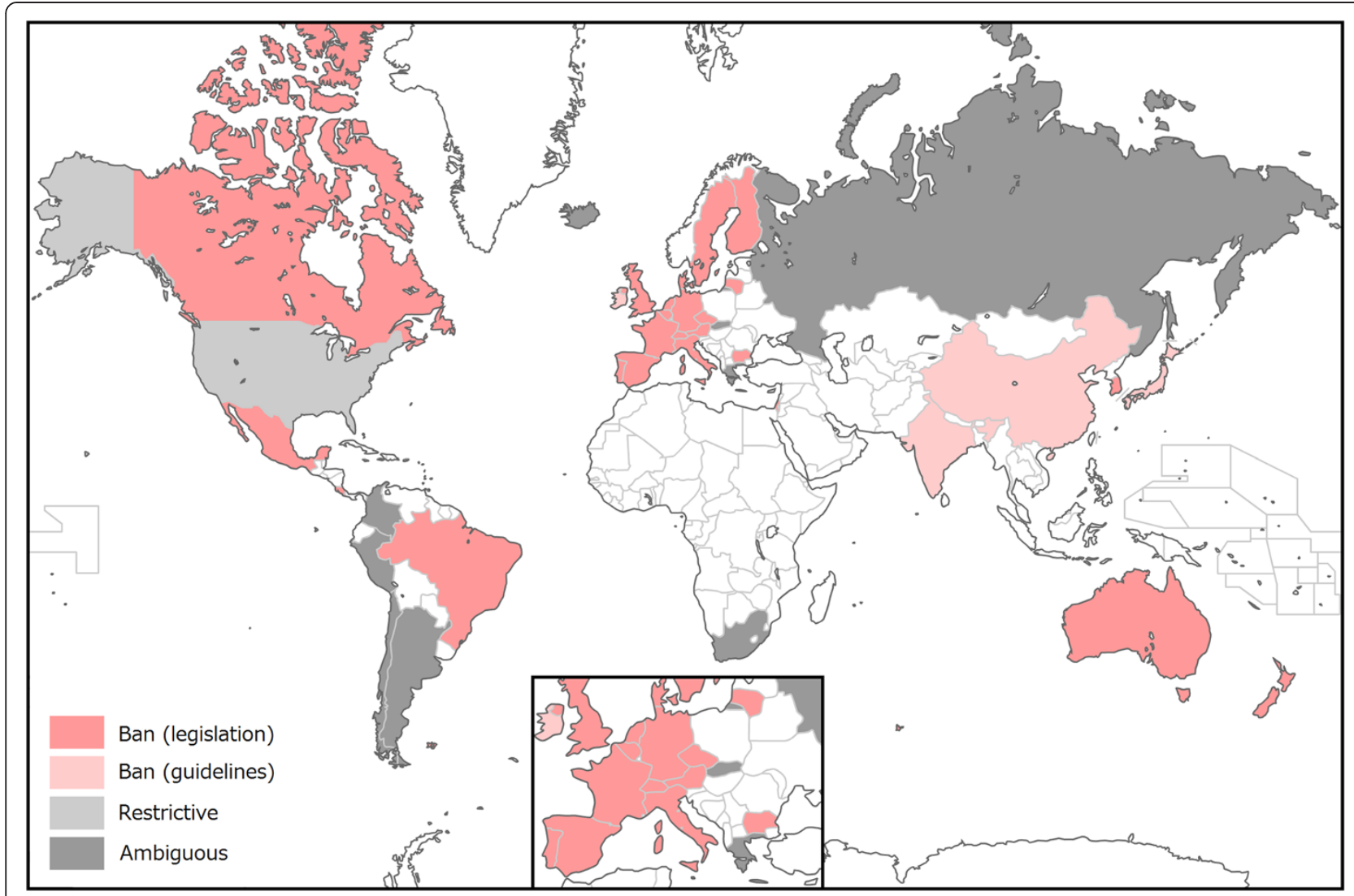

Figure 3 An international regulatory landscape regarding human germline gene modification. Thirty nine countries were surveyed and categorized as "Ban based on legislation" (25, pink), "Ban based on guidelines" (4, faint pink), "Ambiguous" (9, gray), and "Restrictive" (1, light gray). Non-colored countries were excluded in this survey. See also Additional file 1: Table S1.

genome editing can more efficiently correct a mutation in the germline. One would assert that such an act is legal, because the HDR-mediated germline gene correction results in a wild type status that can contribute to normal embryonic development. In contrast, others would dissent from this assertion, because genome editing-mediated germline gene modification can be regarded as a grave intervention in human life. Many arguments are more likely to occur with respect to the lawfulness of genome editing-mediated germline gene modification for medical purposes.

\section{Ethical and social issues}

In an IRB review of an application for the HDRmediated germline gene correction, the unavailability of informed consent from an unborn child may constitute grounds for ethical refusal. Yet, informed consent to the germline gene correction by parents may be justified if its safety is equivalent to that of ART, such as ICSI, which are currently conducted with informed consent provided by prospective parent(s) [9]. Still, there are difficult questions to be addressed. The condition of both parents would be questioned from various viewpoints. For instance, a board member might ask whether a female parent can safely undergo oocyte retrieval which encompasses the need of medication, a hormone injection, and transvaginal retrieval with a potential risk of ovarian hyperstimulation syndrome [82], in addition to pregnancy and delivery. Moreover, another member might ask whether the affected parents can foster the healthy child that was born of the procedure.

From a societal viewpoint, different issues would emerge when genome editing-mediated germline gene correction is practiced for preventive medicine. A regulatory agency would require that practitioners should fulfil long-term monitoring and healthcare of children born using the procedure because it could be associated with a potential risk of health impairment. However, it is difficult to determine how long such children must be monitored. Does the monitoring last during their whole lives or across several generations of the offspring? With regard to the mitochondrial replacement, the UK HFEA declared that it would be necessary to monitor the resulting children during their lifetime and ensure the 
traceability of gametes and embryos [83]. However, it is unlikely to be possible to perform such monitoring in all relevant countries. Moreover, it is also difficult to decide whether a country should aid all patients with thousands of genetic diseases, or how to select the subjects for the preventive medicine. If childbirth with a genetic disease no longer occurs in a country due to the extensive practice of the preventive medicine, it might impact the rights of the disabled with the genetic disease, intentionally or unintentionally assuming a posture against the existing patients who deserve respect, dignity, and support. Social cost of monitoring and healthcare would increase, as the practice of the preventive medicine grows. There is another social issue associated with healthcare costs. ART is generally expensive and creates disparities in access to this infertility services even in a country or a state with insurance coverage $[84,85]$. The access to this preventive medicine would be completely confined to the wealthier segment. Thus, there are many ethical and social issues that should be addressed prior to the initiation of genome editing-mediated germline gene correction for preventive medicine.

\section{Conclusions}

Genome editing-mediated germline gene correction for preventive medicine appears to be an unprecedented event in human history, since humans can correct a genetic mutation in the embryo using this biotechnology and potentially eradicate a congenital anomaly. We predict that corrective genome editing should reach a safe level that permits clinical applications in the immediate future. Each country will need to consider whether corrective genome editing in the human germline should be permitted with respect to socioethical implications as well as safety and efficacy. Furthermore, if a country positively considers the preventive medicine, the country would be required to express preventive measures against abuses of germline genome editing, and a global consensus will need to be formed, because thinking about germline gene modification involves ethical, social, and evolutionary considerations for all of humankind.

\section{Additional file}

Additional file 1: Table S1. Policies on Human Germline Gene Modification for Reproduction Excluding Reproductive Cloning.

\section{Competing interests}

The authors declare that they have no competing interests.

\section{Authors' contributions}

MA and TI examined current development of genome editing in mammals and considered the protocol for germline genome editing. TI surveyed regulations regarding germline gene modification. Tl conceived the study, and MA participated in its design and helped to draft the manuscript. Both authors read and approved the final manuscript.

\section{Acknowledgements}

We thank Kumie Nojima (NIRS) for instructive comments prior to the regulations survey. This work was supported by JSPS KAKENHI Grant Number 26460586 (TI). Our survey contains interpretation. We recommend researchers to consult health authorities in their country.

Received: 15 August 2014 Accepted: 24 September 2014

Published: 24 November 2014

\section{References}

1. Billings PR, Hubbard R, Newman SA: Human germline gene modification: a dissent. Lancet 1999, 353(9167):1873-1875.

2. Frankel MS, Chapman AR: Human Inheritable Genetic Modifications. Assessing Scientific, Ethical, Religious and Policy Issues. In American Association for the Advancement of Sciences. 2000. Search the article by entering the article title at http://shr.aaas.org/projects/human_enhance/ reports/germline.pdf.

3. Davis BD: Germ-line therapy: evolutionary and moral considerations. Hum Gene Ther 1992, 3(4):361-363.

4. Neel JV: Germ-line gene therapy: another view. Hum Gene Ther 1993, 4(2):127-128.

5. Glover J: What Sort of People Should There Be?. London: Penguin Books; 1984:45-47.

6. Lewis CS: The Abolition of Man. New York: Macmillan; 1965:69-71.

7. Ramsey P: Fabricated Man: The Ethics of Genetic Control. New Haven: Yale University Press; 1970.

8. Sandel M: The case against perfection. Atl Mon 2004, 293:51-62.

9. Ishii T: Potential impact of human mitochondrial replacement on global policy regarding germline gene modification. Reprod Biomed Online 2014, 29(2):150-155.

10. Cohen J, Scott R, Schimmel T, Levron J, Willadsen S: Birth of infant after transfer of anucleate donor oocyte cytoplasm into recipient eggs. Lancet 1997, 350(9072):186-187.

11. Brenner CA, Barritt JA, Willadsen S, Cohen J: Mitochondrial DNA heteroplasmy after human ooplasmic transplantation. Fertil Steril 2000 74(3):573-578

12. Barritt JA, Brenner CA, Malter $H E$, Cohen J: Mitochondria in human offspring derived from ooplasmic transplantation. Hum Reprod 2001, 16(3):513-516.

13. FDA: Biological Response Modifiers Advisory Committee. Ooplasm transfer as method to treat female infertility. May 9, 2002. http://www.fda.gov/ohrms/ dockets/ac/cber02.htm\#Biological\%20Response\%20Modifiers.

14. Craven L, Tuppen HA, Greggains GD, Harbottle SJ, Murphy JL, Cree LM, Murdoch AP, Chinnery PF, Taylor RW, Lightowlers RN, Herbert M, Turnbull DM: Pronuclear transfer in human embryos to prevent transmission of mitochondrial DNA disease. Nature 2010, 465(7294):82-85.

15. Paull D, Emmanuele V, Weiss KA, Treff N, Stewart L, Hua H, Zimmer M, Kahler DJ, Goland RS, Noggle SA, Prosser R, Hirano M, Sauer MV, Egli D: Nuclear genome transfer in human oocytes eliminates mitochondrial DNA variants. Nature 2013, 493(7434):632-637.

16. Tachibana M, Amato P, Sparman M, Woodward J, Sanchis DM, Ma H, Gutierrez NM, Tippner-Hedges R, Kang E, Lee HS, Ramsey C, Masterson K, Battaglia D, Lee D, Wu D, Jensen J, Patton P, Gokhale S, Stouffer R, Mitalipov $\mathrm{S}$ : Towards germline gene therapy of inherited mitochondrial diseases. Nature 2013, 493(7434):627-631.

17. FDA: Meeting Materials, Cellular, Tissue and Gene Therapies Advisory Committee. 2014. http://www.fda.gov/AdvisoryCommittees/ CommitteesMeetingMaterials/BloodVaccinesandOtherBiologics/ CellularTissueandGeneTherapiesAdvisoryCommittee/ucm380047.htm.

18. DH: Mitochondrial Donation. In A Consultation Draft Regulations to Permit the Use of New Treatment Techniques to Prevent the Transmission of a Serious Mitochondrial Disease from Mother to Child. 2014. https://www.gov.uk/ government/consultations/serious-mitochondrial-disease-new-techniquesto-prevent-transmission.

19. DH: Mitochondrial donation plans progress following consultation. 2014 https:/www.gov.uk/government/news/mitochondrial-donation-plansprogress-following-consultation.

20. Urnov FD, Rebar EJ, Holmes MC, Zhang HS, Gregory PD: Genome editing with engineered zinc finger nucleases. Nat Rev Genet 2010, 11(9):636-646.

21. Gaj T, Gersbach CA, Barbas CF 3rd: ZFN, TALEN, and CRISPR/Cas-based methods for genome engineering. Trends Biotechnol 2013, 31(7):397-405. 
22. Joung JK, Sander JD: TALENs: a widely applicable technology for targeted genome editing. Nat Rev Mol Cell Biol 2013, 14(1):49-55.

23. Sander JD, Joung JK: CRISPR-Cas systems for editing, regulating and targeting genomes. Nat Biotechnol 2014, 32(4):347-355.

24. Tebas P, Stein D, Tang WW, Frank I, Wang SQ, Lee G, Spratt SK, Surosky RT, Giedlin MA, Nichol G, Holmes MC, Gregory PD, Ando DG, Kalos M, Collman RG, Binder-Scholl G, Plesa G, Hwang WT, Levine BL, June CH: Gene editing of CCR5 in autologous CD4 T cells of persons infected with HIV. N Engl J Med 2014, 370(10):901-910

25. Urnov FD, Miller JC, Lee YL, Beausejour CM, Rock JM, Augustus S, Jamieson AC, Porteus MH, Gregory PD, Holmes MC: Highly efficient endogenous human gene correction using designed zinc-finger nucleases. Nature 2005, 435(7042):646-651.

26. Li H, Haurigot V, Doyon Y, Li T, Wong SY, Bhagwat AS, Malani N, Anguela XM, Sharma R, Ivanciu L, Murphy SL, Finn JD, Khazi FR, Zhou S, Paschon DE, Rebar EJ, Bushman FD, Gregory PD, Holmes MC, High KA: In vivo genome editing restores haemostasis in a mouse model of haemophilia. Nature 2011, 475(7355):217-221.

27. Zou J, Mali P, Huang X, Dowey SN, Cheng L: Site-specific gene correction of a point mutation in human iPS cells derived from an adult patient with sickle cell disease. Blood 2011, 118(17):4599-4608.

28. Sebastiano V, Maeder ML, Angstman JF, Haddad B, Khayter C, Yeo DT, Goodwin MJ, Hawkins JS, Ramirez CL, Batista LF, Artandi SE, Wernig M, Joung JK: In situ genetic correction of the sickle cell anemia mutation in human induced pluripotent stem cells using engineered zinc finger nucleases. Stem Cells 2011, 29(11):1717-1726.

29. Yusa K, Rashid ST, Strick-Marchand H, Varela I, Liu PQ, Paschon DE, Miranda E, Ordonez A, Hannan NR, Rouhani FJ, Darche S, Alexander G, Marciniak SJ, Fusaki N, Hasegawa M, Holmes MC, Di Santo JP, Lomas DA, Bradley A, Vallier $\mathrm{L}$ : Targeted gene correction of alpha1-antitrypsin deficiency in induced pluripotent stem cells. Nature 2011, 478(7369):391-394.

30. Soldner F, Laganiere J, Cheng AW, Hockemeyer D, Gao Q, Alagappan R, Khurana V, Golbe LI, Myers RH, Lindquist S, Zhang L, Guschin D, Fong LK, Vu BJ, Meng X, Urnov FD, Rebar EJ, Gregory PD, Zhang HS, Jaenisch R: Generation of isogenic pluripotent stem cells differing exclusively at two early onset Parkinson point mutations. Cell 2011, 146(2):318-331.

31. Schwank G, Koo BK, Sasselli V, Dekkers JF, Heo I, Demircan T, Sasaki N, Boymans S, Cuppen E, van der Ent CK, Nieuwenhuis EE, Beekman JM, Clevers H: Functional repair of CFTR by CRISPR/Cas9 in intestinal stem cell organoids of cystic fibrosis patients. Cell Stem Cell 2013, 13(6):653-658.

32. Bacman SR, Williams SL, Pinto M, Peralta S, Moraes CT: Specific elimination of mutant mitochondrial genomes in patient-derived cells by mitoTALENs. Nat Med 2013, 19(9):1111-1113.

33. Niu Y, Shen B, Cui Y, Chen Y, Wang J, Wang L, Kang Y, Zhao X, Si W, Li W, Xiang AP, Zhou J, Guo X, Bi Y, Si C, Hu B, Dong G, Wang H, Zhou Z, Li T, Tan T, Pu X, Wang F, Ji S, Zhou Q, Huang X, Ji W, Sha J: Generation of gene-modified cynomolgus monkey via Cas9/RNA-mediated gene targeting in one-cell embryos. Cell 2014, 156(4):836-843.

34. Liu H, Chen Y, Niu Y, Zhang K, Kang Y, Ge W, Liu X, Zhao E, Wang C, Lin S, Jing $B$, Si C, Lin $Q$, Chen $X$, Lin H, Pu X, Wang Y, Qin B, Wang F, Wang H, Si W, Zhou J, Tan T, Li T, Ji S, Xue Z, Luo Y, Cheng L, Zhou Q, Li S: TALENmediated gene mutagenesis in rhesus and cynomolgus monkeys. Cell Stem Cell 2014, 14(3):323-328.

35. Wu Y, Liang D, Wang Y, Bai M, Tang W, Bao S, Yan Z, Li D, Li J: Correction of a genetic disease in mouse via use of CRISPR-Cas9. Cell Stem Cell 2013, 13(6):659-662

36. Lokody I: Genetic therapies: Correcting genetic defects with CRISPRCas9. Nat Rev Genet 2013, 15:63-63.

37. Pollack A: A Powerful New Way to Edit DNA. In The New York Times. 2014

38. Cathomen T, Ehl S: Translating the genomic revolution - targeted genome editing in primates. N Engl J Med 2014, 370(24):2342-2345.

39. Tesson L, Usal C, Menoret S, Leung E, Niles BJ, Remy S, Santiago Y, Vincent Al, Meng X, Zhang L, Gregory PD, Anegon I, Cost GJ: Knockout rats generated by embryo microinjection of TALENs. Nat Biotechnol 2011, 29(8):695-696

40. Yang H, Wang H, Shivalila CS, Cheng AW, Shi L, Jaenisch R: One-step generation of mice carrying reporter and conditional alleles by CRISPR/ Cas-mediated genome engineering. Cell 2013, 154(6):1370-1379.

41. Li W, Teng F, Li T, Zhou Q: Simultaneous generation and germline transmission of multiple gene mutations in rat using CRISPR-Cas systems. Nat Biotechnol 2013, 31(8):684-686.
42. Ran FA, Hsu PD, Lin CY, Gootenberg JS, Konermann S, Trevino AE, Scott DA, Inoue A, Matoba S, Zhang Y, Zhang F: Double nicking by RNA-guided CRISPR Cas9 for enhanced genome editing specificity. Cell 2013, 154(6):1380-1389.

43. Wang $H$, Yang $H$, Shivalila CS, Dawlaty MM, Cheng AW, Zhang F, Jaenisch R: One-step generation of mice carrying mutations in multiple genes by CRISPR/Cas-mediated genome engineering. Cell 2013, 153(4):910-918.

44. Li F, Cowley DO, Banner D, Holle E, Zhang L, Su L: Efficient genetic manipulation of the NOD-Rag1-/-IL2RgammaC-null mouse by combining in vitro fertilization and CRISPR/Cas9 technology. Sci Rep 2014, 4:5290

45. Yasue A, Mitsui SN, Watanabe T, Sakuma T, Oyadomari S, Yamamoto T, Noji S, Mito T, Tanaka E: Highly efficient targeted mutagenesis in one-cell mouse embryos mediated by the TALEN and CRISPR/Cas systems. Sci Rep 2014, 4:5705.

46. Carlson DF, Tan W, Lillico SG, Stverakova D, Proudfoot C, Christian M, Voytas DF, Long CR, Whitelaw CB, Fahrenkrug SC: Efficient TALEN-mediated gene knockout in livestock. Proc Natl Acad Sci U S A 2012, 109(43):17382-17387.

47. Liu Z, Zhou X, Zhu Y, Chen ZF, Yu B, Wang Y, Zhang CC, Nie YH, Sang X, Cai YJ, Zhang YF, Zhang C, Zhou WH, Sun Q, Qiu Z: Generation of a monkey with MECP2 mutations by TALEN-based gene targeting. Neurosci Bull 2014, 30(3):381-386.

48. Mashimo T, Kaneko T, Sakuma T, Kobayashi J, Kunihiro Y, Voigt B, Yamamoto T, Serikawa T: Efficient gene targeting by TAL effector nucleases coinjected with exonucleases in zygotes. Sci Rep 2013, 3:1253.

49. Lombardo A, Genovese P, Beausejour CM, Colleoni S, Lee YL, Kim KA, Ando D, Urnov FD, Galli C, Gregory PD, Holmes MC, Naldini L: Gene editing in human stem cells using zinc finger nucleases and integrase-defective lentiviral vector delivery. Nat Biotechnol 2007, 25(11):1298-1306.

50. Hockemeyer D, Soldner F, Beard C, Gao Q, Mitalipova M, DeKelver RC, Katibah GE, Amora R, Boydston EA, Zeitler B, Meng X, Miller JC, Zhang L, Rebar EJ, Gregory PD, Urnov FD, Jaenisch R: Efficient targeting of expressed and silent genes in human ESCs and iPSCs using zinc-finger nucleases. Nat Biotechnol 2009, 27(9):851-857.

51. Hockemeyer D, Wang H, Kiani S, Lai CS, Gao Q, Cassady JP, Cost GJ, Zhang L, Santiago Y, Miller JC, Zeitler B, Cherone JM, Meng X, Hinkley SJ, Rebar EJ, Gregory PD, Urnov FD, Jaenisch R: Genetic engineering of human pluripotent cells using TALE nucleases. Nat Biotechnol 2011, 29(8):731-734.

52. Zou J, Maeder ML, Mali P, Pruett-Miller SM, Thibodeau-Beganny S, Chou BK, Chen G, Ye Z, Park IH, Daley GQ, Porteus MH, Joung JK, Cheng L: Gene targeting of a disease-related gene in human induced pluripotent stem and embryonic stem cells. Cell Stem Cell 2009, 5(1):97-110.

53. Li W, Li X, Li T, Jiang MG, Wan H, Luo GZ, Feng C, Cui X, Teng F, Yuan $Y$, Zhou Q, Gu Q, Shuai L, Sha J, Xiao Y, Wang L, Liu Z, Wang XJ, Zhao XY, Zhou Q: Genetic modification and screening in rat using haploid embryonic stem cells. Cell Stem Cell 2014, 14(3):404-414.

54. Glass B: Science: endless horizons or golden age? Science 1971, 171(3966):23-29.

55. WHO: Congenital anomalies. Fact sheet No 370. 2014. http://www.who. int/mediacentre/factsheets/fs370/en/.

56. Neocleous V, Yiallouros PK, Tanteles GA, Costi C, Moutafi M: Apparent Homozygosity of p.Phe508del in CFTR due to a Large Gene Deletion of Exons 4-11. Case Rep Genet 2014, 2014:613863.

57. Groselj U, Tansek MZ, Kovac J, Hovnik T, Podkrajsek KT, Battelino T: Five novel mutations and two large deletions in a population analysis of the phenylalanine hydroxylase gene. Mol Genet Metab 2012, 106(2):142-148.

58. Squitieri F, Gellera C, Cannella M, Mariotti C, Cislaghi G, Rubinsztein DC, Almqvist EW, Turner D, Bachoud-Levi AC, Simpson SA, Delatycki M, Maglione V, Hayden MR, Donato SD: Homozygosity for CAG mutation in Huntington disease is associated with a more severe clinical course. Brain 2003, 126(Pt 4):946-955.

59. Cruz-Correa M, Diaz-Algorri Y, Mendez V, Vazquez PJ, Lozada ME, Freyre K, Lathroum L, Gonzalez-Pons M, Hernandez-Marrero J, Giardiello F, RodriguezQuilichini S: Clinical characterization and mutation spectrum in Hispanic families with adenomatous polyposis syndromes. Familial Cancer 2013, 12(3):555-562.

60. Stern HJ: Preimplantation Genetic Diagnosis: Prenatal Testing for Embryos Finally Achieving Its Potential. J Clin Med 2014, 3(1):280-309.

61. Hauschild J, Petersen B, Santiago Y, Queisser AL, Carnwath JW, Lucas-Hahn A, Zhang L, Meng X, Gregory PD, Schwinzer R, Cost GJ, Niemann H: Efficient generation of a biallelic knockout in pigs using zinc-finger nucleases. Proc Natl Acad Sci U S A 2011, 108(29):12013-12017. 
62. Tachibana M, Amato P, Sparman M, Gutierrez NM, Tippner-Hedges R, Ma H, Kang E, Fulati A, Lee HS, Sritanaudomchai H, Masterson K, Larson J, Eaton D, Sadler-Fredd K, Battaglia D, Lee D, Wu D, Jensen J, Patton P, Gokhale S, Stouffer RL, Wolf D, Mitalipov S: Human embryonic stem cells derived by somatic cell nuclear transfer. Cell 2013, 153(6):1228-1238.

63. Chung YG, Eum JH, Lee JE, Shim SH, Sepilian V, Hong SW, Lee Y, Treff NR, Choi YH, Kimbrel EA, Dittman RE, Lanza R, Lee DR: Human somatic cell nuclear transfer using adult cells. Cell Stem Cell 2014, 14(6):777-780.

64. Yamada M, Johannesson B, Sagi I, Burnett LC, Kort DH, Prosser RW, Paull D, Nestor MW, Freeby M, Greenberg E, Goland RS, Leibel RL, Solomon SL, Benvenisty N, Sauer MV, Egli D: Human oocytes reprogram adult somatic nuclei of a type 1 diabetic to diploid pluripotent stem cells. Nature 2014, 510(7506):533-536.

65. Laurent LC, Ulitsky I, Slavin I, Tran H, Schork A, Morey R, Lynch C, Harness JV, Lee S, Barrero MJ, Ku S, Martynova M, Semechkin R, Galat V, Gottesfeld J, Izpisua Belmonte JC, Murry C, Keirstead HS, Park HS, Schmidt U, Laslett AL, Muller FJ, Nievergelt CM, Shamir R, Loring JF: Dynamic changes in the copy number of pluripotency and cell proliferation genes in human ESCs and iPSCs during reprogramming and time in culture. Cell Stem Cell 2011, 8(1):106-118.

66. Taapken SM, Nisler BS, Newton MA, Sampsell-Barron TL, Leonhard KA, McIntire EM, Montgomery KD: Karotypic abnormalities in human induced pluripotent stem cells and embryonic stem cells. Nat Biotechnol 2011, 29(4):313-314.

67. Amps K, Andrews PW, Anyfantis G, Armstrong L, Avery S, Baharvand $H$, Baker J, Baker D, Munoz MB, Beil S, Benvenisty N, Ben-Yosef D, Biancotti JC, Bosman A, Brena RM, Brison D, Caisander G, Camarasa MV, Chen J, Chiao E, Choi YM, Choo AB, Collins D, Colman A, Crook JM, Daley GQ, Dalton A, De Sousa PA, Denning C, Downie J, et al: Screening ethnically diverse human embryonic stem cells identifies a chromosome 20 minimal amplicon conferring growth advantage. Nat Biotechnol 2011, 29(12):1132-1144.

68. Van Haute L, Spits C, Geens M, Seneca S, Sermon K: Human embryonic stem cells commonly display large mitochondrial DNA deletions. Nat Biotechnol 2013, 31(1):20-23.

69. Benn P: Non-Invasive Prenatal Testing Using Cell Free DNA in Maternal Plasma: Recent Developments and Future Prospects. J Clin Med 2014, 3(1):537-565.

70. Bielanska M, Tan SL, Ao A: Chromosomal mosaicism throughout human preimplantation development in vitro: incidence, type, and relevance to embryo outcome. Hum Reprod 2002, 17(2):413-419.

71. Bielanska M, Tan SL, Ao A: High rate of mixoploidy among human blastocysts cultured in vitro. Fertil Steril 2002, 78(6):1248-1253.

72. Van Echten-Arends J, Mastenbroek S, Sikkema-Raddatz B, Korevaar JC, Heineman MJ, van der Veen F, Repping S: Chromosomal mosaicism in human preimplantation embryos: a systematic review. Hum Reprod Update 2011, 17(5):620-627.

73. Scott RT Jr, Upham KM, Forman EJ, Zhao T, Treff NR: Cleavage-stage biopsy significantly impairs human embryonic implantation potential while blastocyst biopsy does not: a randomized and paired clinical trial. Fertil Steril 2013, 100(3):624-630.

74. Gaj T, Guo J, Kato Y, Sirk SJ, Barbas CF 3rd: Targeted gene knockout by direct delivery of zinc-finger nuclease proteins. Nat Methods 2012, 9(8):805-807.

75. van der Gaast MH, Eijkemans MJ, van der Net JB, De Boer EJ, Burger CW Van Leeuwen FE, Fauser BC, Macklon NS: Optimum number of oocytes for a successful first IVF treatment cycle. Reprod Biomed Online 2006, 13 (4):476-480.

76. Sunkara SK, Rittenberg V, Raine-Fenning N, Bhattacharya S, Zamora J, Coomarasamy A: Association between the number of eggs and live birth in IVF treatment: an analysis of 400135 treatment cycles. Hum Reprod 2011, 26(7):1768-1774

77. Fu Y, Sander JD, Reyon D, Cascio VM, Joung JK: Improving CRISPR-Cas nuclease specificity using truncated guide RNAs. Nat Biotechnol 2014, 32(3):279-284.

78. Guilinger JP, Thompson DB, Liu DR: Fusion of catalytically inactive Cas9 to Fokl nuclease improves the specificity of genome modification. Nat Biotechnol 2014, 32(6):577-582.

79. Ishii T, Pera RA, Greely HT: Ethical and legal issues arising in research on inducing human germ cells from pluripotent stem cells. Cell Stem Cell 2013, 13(2):145-148.

80. Wong CC, Johnson MH: Therapy for mitochondrial genetic disease: are we at the thin end of the wedge? Reprod Biomed Online 2014, 29(2):147-149.
81. Araki $M$, Nojima $K$, Ishii $\mathrm{T}$ : Caution required for handling genome editing technology. Trends Biotechnol 2014, 32(5):234-237.

82. Orvieto R: Ovarian hyperstimulation syndrome- an optimal solution for an unresolved enigma. J Ovarian Res 2013, 6(1):77.

83. HFEA: HFEA Statement Regarding the Klaus Reinhardt et al. Science Paper 'Mitochondrial Replacement, Evolution, and the Clinic'. 2013. http://www.hfea.gov.uk/8178.html.

84. Jain T, Hornstein MD: Disparities in access to infertility services in a state with mandated insurance coverage. Fertil Steril 2005, 84(1):221-223.

85. Nachtigall RD: International disparities in access to infertility services. Fertil Steril 2006, 85(4):871-875.

doi:10.1186/1477-7827-12-108

Cite this article as: Araki and Ishii: International regulatory landscape and integration of corrective genome editing into in vitro fertilization. Reproductive Biology and Endocrinology 2014 12:108.

\section{Submit your next manuscript to BioMed Central and take full advantage of:}

- Convenient online submission

- Thorough peer review

- No space constraints or color figure charges

- Immediate publication on acceptance

- Inclusion in PubMed, CAS, Scopus and Google Scholar

- Research which is freely available for redistribution

Submit your manuscript at www.biomedcentral.com/submit
C) BioMed Central 